\title{
Minimal Input Production Systems Affect Yield and Juice Quality of 'Sunbelt' Grapes in California's San Joaquin Valley
}

\author{
R. Keith Striegler and Chris B. Lake \\ Department of Horticulture, PTSC 310, University of Arkansas, Fayetteville, \\ AR 72701-1201
}

Justin R. Morris, Renee T. Threlfall, and Gary L. Main
Institute of Food Science and Engineering, University of Arkansas, 2650 North
Young Avenue, Fayetteville, AR 72704

Simon G. Graves ${ }^{1}$

Viticulture and EnologyResearch Center,2360 East Barstow Avenue, California State University, Fresno, CA 93740-0089 Additional index words. Vitis labruscana, mechanization, minimal pruning, sustainable
viticulture

\begin{abstract}
Sunbelt' is a juice grape cultivar developed by the Univ. of Arkansas. This cultivar produces 'Concord'-type juice and is adapted to warm climatic conditions of the southern United States. Preliminary evaluation showed that 'Sunbelt' has potential to produce high-quality juice under the hot climatic conditions of the San Joaquin Valley. A study was conducted during the 1998 and 1999 growing seasons to further evaluate the adaptation of 'Sunbelt' to the San Joaquin Valley and determine the response of this cultivar to selected pruning methods. Vines were grown for two seasons without use of insecticides, fungicides, or herbicides. Vines were subjected to four pruning treatments: severe hand pruning (60-80 nodes retained/vine); moderate hand pruning (120-160 nodes retained/vine); machine pruning with hand follow-up (160-180 nodes retained/vine); and minimal pruning (200-400 nodes retained/vine). Vines were trained to a Geneva Double Curtain trellis system. Yield, components of yield, and juice quality were significantly impacted by pruning treatment. In both seasons, mechanized systems of pruning (machine and minimal) produced higher yield than hand pruning. Minimal pruning resulted in the highest yield $\left(42 \mathrm{t} \cdot \mathrm{ha}^{-1}\right)$ in 1998 , while yield from the machine-pruned vines was highest $\left(29 \mathrm{t}^{\mathrm{h}} \mathrm{h}^{-1}\right)$ in 1999. Minimally pruned vines had the highest clusters/vine and lowest cluster weight among the treatments. The extremely high yields obtained for the minimal pruning treatments produced fruit that was less mature resulting in juice with lower soluble solids than the other treatments in 1998. However, in 1999 the juice from minimally pruned vines had the highest soluble solids. Sensory analysis of juice produced in 1999 showed that the juice from the machine-pruned treatment had the least color intensity. Sensory analysis showed that minimal and severe hand pruning were ranked higher for sweetness than machine and moderate hand pruning. In the second year of the study, the juice from the minimal-pruned and severe hand-pruned treatment were preferred over the moderate hand-pruned treatment or the machine-pruned treatment.
\end{abstract}

Grape production for juice concentrate is an important market for grape growers in the San Joaquin Valley (Bedwell, 1998; Larsen, 2000). In 1999 , over 680,400 t of grapes were crushed for juice concentrate production. This quantity represented $\approx 25 \%$ of the total U.S. crush (California Agricultural Statistics Service, 2000). The majority of grapes crushed for juice concentrate were white cultivars,

Received for publication 5 Apr. 2001. Accepted for publication 10 Nov. 2001. Published with the approval of the Director, Arkansas Agricultural Experiment Station. We further acknowledge the financial support of Simpson Farm Company, Madera, Calif., for this research.

${ }^{1}$ Current address: Southcorp Wine Estates, 3990 Ryan Rd., Creston, CA 93432. E-mail: kstrig@uark.edu primarily 'Thompson Seedless' (Vitis vinifera $\mathrm{L}$.). However, red cultivars such as 'Royalty' and 'Rubired' (mixed species hybrid) were also used for concentrate production.

'Concord' (Vitis labruscana Bailey) is the predominant grape cultivar grown in U.S. viticultural regions outside California. 'Concord' juice has a strong, unique flavor and deep purple color. It is used for production of single strength juice, concentrate, wine, and processed products including beverages, fruit spreads, frozen dessert bars, yogurt base, pie mixes, powders, and crystals. Demand for 'Concord' juice concentrate has been strong in recent years (Barber, 1997; Blevins and Morris 1997; Morris, 1998; Morris and Striegler, 1996). This trend has been influenced by health benefits of grape product consumption associated with reduction of cholesterol, decreased cardiovascular disease, and prevention of cancer (Bisson et al., 1995; Blevins and Morris, 1997; Fitzpatrick et al., 1993; Jang et al., 1997). Consumers perceive red grape juice as healthy and flavorful; however, 'Concord' grapes are essentially a specialty crop because production is limited to Washington, Michigan, and the Lake Erie belt (New York-Pennsylvania-Ohio). 'Concord' production limitations include growing season length for potential northern growing regions and excessive heat for potential southern growing regions. Regions with excessive heat during the growing season typically produce poor quality fruit and juice because of uneven ripening.

'Concord' grape production was attempted in the San Joaquin Valley, but growth, yield, and fruit composition were adversely impacted by the hot growing conditions. In an attempt to establish a 'Concord'-type cultivar for California, the Dept. of Viticulture and Enology, Univ. of California, Davis introduced 'Niabell' and 'Early Niabell'. However, these cultivars have been used primarily in the home garden and only a few commercial vineyards (Olmo and Koyama, 1962).

The Arkansas Agricultural Experiment Station released the juice grape cultivar, 'Sunbelt' (Vitis labruscana Bailey) in 1993 (Moore et al., 1993). 'Sunbelt' fulfills the need for a processing grape that can be grown in hot areas where 'Concord' grapes display uneven fruit ripening associated with high temperatures (Morris et al., 1984). 'Sunbelt' is similar to 'Concord' in most plant and fruit characteristics, differing primarily in its ability to ripen evenly under high temperatures.

Clusters are small; berries are blue, large and seeded. Soluble solids concentration and harvest date correspond closely with those of 'Concord' when compared under hot climatic conditions. However, the color, acidity, and $\mathrm{pH}$ of 'Sunbelt' are superior to 'Concord' for juice production (Moore et al., 1993). In preliminary studies 'Sunbelt' had good flavor and aroma characteristics when grown in the San Joaquin Valley (Haight et al., 1995).

Fruit and juice quality can be greatly influenced by pruning methods. In Arkansas, shootpositioned 'Concord' grapevines trained to Geneva Double Curtain, or high wire, bilateral cordon systems were used in studies that determined the effects of mechanical pruning on yield, vine size, and juice quality (Morris and Cawthon, 1980a, 1980b, 1980c, 1981; Morris et al., 1984). Continual mechanical pruning is most effective when adequate shoot or fruit limitation follows pruning to prevent poor juice quality due to over-cropping.

Estimates indicate that $60 \%$ of Australian wine grape vineyards are pruned mechanically, leading to substantial savings in production costs (Clingeleffer, 1993; Clingeleffer and Possingham, 1987). Minimal pruning (vines trained on a high wire single trellis, left unpruned, and then skirted) overcame problems such as costs associated with conventional hand pruning and internal canopy shading and reduced quality associated with severe mechanical pruning (Clingeleffer, 
1989). Minimal pruning trials conducted over 17 seasons, primarily in warm climate regions, showed that the vine has the capacity, through balanced growth, to maintain its shape, productivity, and fruit quality (Clingeleffer, 1993). Minimal pruning is also used in cooler regions in Australia. However, successful adoption of this technology for high-yielding, vigorous vines in cooler regions often requires use of crop control to restrict yield so that adequate fruit maturity and wine quality can be achieved (Clingeleffer, 1992).

Since there is limited research on 'Sunbelt' grapes, a study was established to further evaluate the suitability of 'Sunbelt' grapevines for production of high quality 'Concord'-type juice products in the San Joaquin Valley and evaluate pruning treatments to optimize yield, fruit composition, and juice quality. Furthermore, production of commercially acceptable 'Sunbelt' juice would provide growers in the southern San Joaquin Valley with a potential new market for grapes.

\section{Materials and Methods}

'Sunbelt' was grafted onto mature, ownrooted 'Chenin blanc' vines in a commercial vineyard near Madera, Calif., in 1991. The soil type was a Hanford Sandy Loam (coarseloamy, mixed nonacid, thermic Typic Xerothents). Vineyard spacing was $2.1 \times 3.6 \mathrm{~m}$ (vine $\times$ row). The trellis/training system was a Geneva Double Curtain with a 1.8-m cordon height and cross arm width of $1.2 \mathrm{~m}$. The vineyard was drip irrigated. No fungicides, insecticides, or herbicides were applied. There were no fruit losses due to vine diseases or insect pests during the course of the study. Resident vegetation was allowed to grow in row middles and under-the-row vegetation was controlled by mechanical cultivation. Row middles were cultivated about two times each season to control growth.

Pruning treatments and canopy management. Pruning treatments were established during the 1997-98 dormant season. Treatments included vines that were: 1) severely hand pruned to retain $60-80$ nodes/vine; 2 ) moderately hand pruned to retain $120-160$ nodes/vine; 3 ) machine pruned in a $3.6 \times 3.6$ $\mathrm{cm}$ box cut centered on the cordon (160-180 nodes/vine retained); and 4) minimally pruned (no dormant season pruning with 200-400 nodes/vine retained). Fruiting wood was retained on hand-pruned vines as five node canes.

Hand-pruned vines were shoot positioned downward and all canopy middles were separated twice in June and July to maintain two distinct canopies during the growing season. Canopy separation was also imposed on machine-pruned vines. Minimally pruned vines were trimmed $0.76 \mathrm{~m}$ from the soil surface at berry set.

Five vines in each plot were harvested and yield data collected. Clusters per vine, yield per vine, berry weight, and berries per cluster were determined. Mature nodes were counted immediately preceding dormant pruning. A node was considered to be mature when internode regions distal and proximal to the node had periderm. Pruning weights were determined for hand- and machine-pruned vines. Nodes retained per vine were counted following dormant pruning.

Fruithandling and juice production. Handharvested fruit was shipped overnight to the Institute of Food Science and Engineering at the Univ. of Arkansas, Fayetteville for juice processing and analysis. The grapes were crushed and de-stemmed. The must was heated in a steam kettle to $60^{\circ} \mathrm{C}$ while being continuously stirred. A pectolytic enzyme, Scottzyme Pec5L (Scott Laboratories, Petaluma, Calif.), was added at $2 \mathrm{~mL} / 440 \mathrm{~kg}$ and the must was held at $60{ }^{\circ} \mathrm{C}$ for $10 \mathrm{~min}$ while being stirred. The must was cooled to $39^{\circ} \mathrm{C}$ and pressed in a \#70 Enrossi bladder type press (Enoagricol Rossi s.r.l., Calzolaro, Italy) at 4 ata using press cloths. The juice was held at $2{ }^{\circ} \mathrm{C}$ for $30 \mathrm{~d}$ for tartrate precipitation and then ultrafiltered $(500,000 \mathrm{MW})$, pasteurized at $88^{\circ} \mathrm{C}$, and bottled.

Lab analysis. Juices were analyzed for soluble solids, $\mathrm{pH}$, titratable acidity, and concentration of total red pigments as measured by the absorbance at $520 \mathrm{~nm}$ of juice acidified to $\mathrm{pH} 3.5$ (Iland et al., 1993).

The soluble solids of the fruit and juice were measured by using a Reichart ABBE Mark II Bausch and Lomb refractometer (Scientific Instruments, Keene, N.H.). An automated titrimeter and electrode standardized to $\mathrm{pH} 4.00$ and $\mathrm{pH} 7.00$ buffers were used to measure $\mathrm{pH}$ and titratable acidity. Titratable acidity was determined by titration with $0.1 \mathrm{~N}$ sodium hydroxide to an endpoint of $\mathrm{pH} 8.2$. Titratable acidity was expressed as percent tartaric acid.

Sensory analysis. Sensory analysis was conducted on juice produced in 1999. Thirtytwo panelists, who were consumers of grape juice, ranked sensory characteristics. The ranking test is an extension of the paired comparison test in which the panelist ranks the samples for intensity of a specific characteristic (Poste et al., 1991). Four samples of juice from the four treatments were presented to panelists at $21^{\circ} \mathrm{C}$ in 60 -mL clear plastic soufflé cups with lids. Sample containers were labeled with threedigit random code numbers to eliminate indi-

Table 1. Effect of pruning systems on yield and yield components of 'Sunbelt' grapevines in 1998 and 1999.

\begin{tabular}{|c|c|c|c|c|c|c|c|c|}
\hline $\begin{array}{l}\text { Pruning } \\
\text { systems } \\
\text { and season }\end{array}$ & $\begin{array}{c}\text { Nodes } \\
\text { retained/ } \\
\text { vine }^{\mathrm{z}}\end{array}$ & $\begin{array}{c}\text { Yield } \\
\left(\mathrm{t} \cdot \mathrm{ha}^{-1}\right)\end{array}$ & $\begin{array}{c}\text { Clusters/ } \\
\text { vine }\end{array}$ & $\begin{array}{c}\text { Cluster } \\
\text { wt } \\
(\mathrm{g})\end{array}$ & $\begin{array}{r}\text { Berries/ } \\
\text { cluster }\end{array}$ & $\begin{array}{c}\text { Berry } \\
\text { wt } \\
(\mathrm{g})\end{array}$ & $\begin{array}{c}\text { Mature } \\
\text { nodes/ } \\
\text { vine }\end{array}$ & $\begin{array}{l}\text { Dormant } \\
\text { prunings } \\
\text { (kg/vine) }\end{array}$ \\
\hline \multicolumn{9}{|c|}{1998} \\
\hline Severe hand & $79 \mathrm{c}$ & $23.2 \mathrm{c}^{\mathrm{y}}$ & $74 \mathrm{c}$ & $245 \mathrm{a}$ & $77 \mathrm{a}$ & 3.2 & $303 \mathrm{a}$ & 0.93 \\
\hline Moderate hand & $144 b$ & $31.0 \mathrm{~b}$ & $97 \mathrm{bc}$ & $248 \mathrm{a}$ & $76 a$ & 3.3 & $305 \mathrm{a}$ & 1.25 \\
\hline Machine & $174 \mathrm{~b}$ & $35.5 \mathrm{ab}$ & $118 \mathrm{~b}$ & $237 \mathrm{a}$ & $69 a$ & 3.5 & $299 a$ & 1.03 \\
\hline Minimal & $\begin{array}{c}317 \mathrm{a} \\
* * *\end{array}$ & $\begin{array}{c}42.0 \mathrm{a} \\
* * *\end{array}$ & $\begin{array}{l}243 \mathrm{a} \\
* * *\end{array}$ & $\underset{* * *}{136 \mathrm{~b}}$ & $\begin{array}{l}48 \mathrm{~b} \\
*\end{array}$ & $\begin{array}{l}3.0 \\
\text { NS }\end{array}$ & $\begin{array}{l}203 \mathrm{~b} \\
* * *\end{array}$ & $---x$ \\
\hline \multicolumn{9}{|c|}{1999} \\
\hline Severe hand & $68 d$ & $21.6 \mathrm{~b}$ & $128 \mathrm{~b}$ & $132 \mathrm{a}$ & $41 \mathrm{a}$ & 3.2 & 498 & 1.28 \\
\hline Moderate hand & $117 \mathrm{c}$ & $21.6 \mathrm{~b}$ & $123 \mathrm{~b}$ & $138 \mathrm{a}$ & $40 \mathrm{a}$ & 3.4 & 403 & 1.13 \\
\hline Machine & $160 \mathrm{~b}$ & $29.9 \mathrm{a}$ & $166 \mathrm{a}$ & $141 \mathrm{a}$ & $43 \mathrm{a}$ & 3.3 & 486 & 0.63 \\
\hline \multirow[t]{2}{*}{ Minimal } & $\begin{array}{c}203 \text { a } \\
* * *\end{array}$ & $\begin{array}{c}25.0 \mathrm{ab} \\
* *\end{array}$ & $\begin{array}{c}199 \mathrm{a} \\
* *\end{array}$ & $\underset{* * *}{99 \mathrm{~b}}$ & $\begin{array}{c}33 \mathrm{~b} \\
*\end{array}$ & 3.1 & 474 & --- \\
\hline & & & & & & NS & NS & \\
\hline
\end{tabular}

${ }^{2}$ The nodes retained in the preceding dormant season.

${ }^{y}$ Means within column and year with the same letters are not significantly different at $\alpha \leq 0.05$.

${ }^{x}$ Data not analyzed statically due to inclusion of minimal pruning treatment.

ns, *,**,*** Nonsignificant or significant at $\alpha \leq 0.05 ; 0.01$, or 0.001 , respectively. 
have produced this result immediately and eliminated the low soluble solids and poor quality associated with minimal pruning during 1998. Previous studies showed that mechanical thinning can reduce season to season variability in yield and vegetative growth (Clingeleffer, 1992).

As expected, minimally pruned vines had the highest number of nodes/vine in both years while severe hand pruning resulted in the lowest number of nodes/vine. Minimal pruning had the least number of mature nodes/vine in 1998, but there were no differences between pruning methods for this variable in 1999.

Quality of juice. In general, for a given pruning treatment, yield and quality were inversely related. This is especially true under extremely high yielding situations.

In 1998, the minimal pruning treatment resulted in juice with lower quality than the other treatments (Table 2). Soluble solids for the minimal treatment $(11.5 \%)$ were lower than the other treatments. The highest soluble solids concentrations $(15.2 \%)$ was in the juice produced from the severe hand pruning treatment. The $\mathrm{pH}$ and titratable acidity were similar for all treatments in both years.

Juice produced in 1999 from the minimal pruning treatment was of higher quality than the 1998 juice from this pruning treatment. Juice from minimal-pruned and severe handpruned vines had the highest soluble solids concentrations $(19.2 \%)$, while the machinepruned vines had the lowest soluble solids concentrations (16.6\%). In 1998, juice from the minimally pruned vines had the lowest concentration of total red pigments but had the highest in 1999.

Sensory of juice. Sensory analysis was conducted on 'Sunbelt' juice produced in 1999 (Table 3). The panelists ranked the juice by intensity of color, aroma, flavor, sweetness, and overall preference. The panelists were able to detect a difference in intensity of color, sweetness, and overall preference among juices from the pruning treatments but were unable to detect any differences among the treatments in terms of the intensity of aroma and flavor. Smith et al. (1996) reported that pruning affected color but few differences were found in terms of aroma and flavor. The machine-pruned treatment had lower color intensity than the other pruning treatments. The minimal and severe pruning treatments were ranked higher for sweetness than the machine and moderate pruning treatments. The sensory data corresponded to the soluble solids concentrations as determined by analysis of the juice. Assessment of the overall preference data indicated that juice from minimally pruned vines was preferred over juice from machine-pruned or moderately hand-pruned vines.

In summary, this study provided information on adaptation of 'Sunbelt' grapevines to San Joaquin Valley conditions and on the response of this cultivar to production systems which feature minimal input of labor and agricultural chemicals. In this study, 'Sunbelt' was produced without the use of insecticides, fungicides, and herbicides. Thus, growers and juice processors in the San Joaquin Valley could utilize 'Sunbelt' in the production of high quality 'Concord'-type juice that would meet the requirements for organic certification. In both seasons, high quality 'Concord'type juice was produced from 'Sunbelt' grapes. This result confirmed the preliminary assessment of the potential of 'Sunbelt' grapevines grown in the San Joaquin Valley (Haight et al., 1995).

In both seasons, mechanized pruning treatments impacted yield, yield components, and juice quality. Yield increased when mechanized pruning left high numbers of buds

Table 2. Effect of pruning systems on quality of 'Sunbelt' grape juice in 1998 and 1999.

\begin{tabular}{|c|c|c|c|c|}
\hline $\begin{array}{l}\text { Pruning systems } \\
\text { and season }\end{array}$ & $\begin{array}{c}\text { Soluble solids } \\
(\%)\end{array}$ & $\mathrm{pH}$ & $\begin{array}{c}\text { Titratable acidity } \\
(\% \text { Tartaric })\end{array}$ & $\begin{array}{c}\text { Absorbance@ } \\
520 \text { nm acidified }\end{array}$ \\
\hline \multicolumn{5}{|c|}{1998} \\
\hline Severe hand & $15.2 \mathrm{a}^{\mathrm{z}}$ & $3.34 \mathrm{a}$ & 0.78 & $46.0 \mathrm{a}$ \\
\hline Moderate hand & $14.1 \mathrm{a}$ & $3.33 \mathrm{a}$ & 0.73 & $38.5 \mathrm{ab}$ \\
\hline Machine & $13.9 \mathrm{a}$ & $3.34 \mathrm{a}$ & 0.75 & $36.6 \mathrm{~b}$ \\
\hline \multirow[t]{2}{*}{ Minimal } & $11.5 \mathrm{~b}$ & $3.25 \mathrm{a}$ & 0.79 & $25.8 \mathrm{c}$ \\
\hline & \multicolumn{3}{|c|}{1999} & ** \\
\hline Severe hand & $19.2 \mathrm{a}$ & 3.29 & 0.74 & $104.7 \mathrm{a}$ \\
\hline Moderate hand & $17.1 \mathrm{~b}$ & 3.26 & 0.74 & $86.8 \mathrm{~b}$ \\
\hline Machine & $16.6 \mathrm{~b}$ & 3.32 & 0.74 & $87.0 \mathrm{~b}$ \\
\hline \multirow[t]{2}{*}{ Minimal } & $19.2 \mathrm{a}$ & 3.35 & 0.74 & $105.3 \mathrm{a}$ \\
\hline & $* *$ & NS & NS & $* *$ \\
\hline
\end{tabular}

${ }^{\mathrm{z}}$ Means within column and year with the same letters are not significantly different at $\alpha \leq 0.05$. Ns, *,**Nonsignificant or significant at $\alpha=0.05$ and 0.01 , respectively.

Table 3. Effect of pruning systems on sensory rankings for color, aroma, flavor, sweetness, and overall preference of 'Sunbelt' grape juice in 1999.

\begin{tabular}{lccccc}
\hline Pruning systems & Color & Aroma & Flavor & Sweetness & Overall preference \\
\hline Severe hand & $56 \mathrm{~b}^{2}$ & $79 \mathrm{a}$ & $82 \mathrm{a}$ & $56 \mathrm{~b}$ & $73 \mathrm{ab}$ \\
Moderate hand & $75 \mathrm{~b}$ & $70 \mathrm{a}$ & $80 \mathrm{a}$ & $107 \mathrm{a}$ & $92 \mathrm{a}$ \\
Machine & $115 \mathrm{a}$ & $91 \mathrm{a}$ & $76 \mathrm{a}$ & $98 \mathrm{a}$ & $91 \mathrm{a}$ \\
Minimal & $74 \mathrm{~b}$ & $80 \mathrm{a}$ & $82 \mathrm{a}$ & $59 \mathrm{~b}$ & $64 \mathrm{~b}$ \\
\hline
\end{tabular}

${ }^{\mathrm{z}}$ Any two rank sums within a column not followed by the same letter are significantly different at $P \leq 0.05$. Low rank sum values indicate more color, aroma, flavor, sweetness, and preference. remaining on the vines. Pruning studies have demonstrated increased yield for mechanical pruning (Morris and Cawthon, 1980a, 1980b, 1980c, 1981; Pool et al., 1993) and minimal pruning (Clingeleffer, 1989; Fendinger et al., 1996). Minimally pruned vines displayed significant changes in yield components when compared to vines from the other treatments. Minimal pruning resulted in an increase in clusters/vine and a reduction in cluster weight and berries/cluster.

Juice quality, as determined by chemical and sensory analysis, was related to vine yield. The high yield obtained for mechanized pruning treatments in 1998 had a negative impact on juice quality. Fruit reduction by mechanical thinning could have been used to balance the vine's production and improve juice quality in 1998. This practice is currently being done in commercial vineyards in New York and Arkansas (Morris, 2000; Pool et al., 1993). During the 1999 season, juice quality was highest for severe hand- and minimal-pruned vines.

Further research is needed to assess the long term effects of these practices and to demonstrate the inclusion of mechanical thinning into the production systems evaluated in this study.

\section{Literature Cited}

Barber, H. 1997. The industrial Concord market from a broker's viewpoint. Proc. Washington State Grape Soc. Annu. Mtg., Grandview, Wash. 20 Nov.

Bedwell, B. 1998. Looking at the 1998 California grape crush. Amer. Vineyard 7(12):6-9, 34

Bisson, L.F., C.E. Butzke, and S.E. Ebeler. 1995. The role of moderate ethanol consumption in health and human nutrition. Amer. J. Enol. and Viticult. 46:449-462.

Blevins, J.M. and J.R. Morris. 1997. Health benefits of wine and grape juice. HortTechnology 7:228-33

California Agricultural Statistics Service. 2000. Grape crush report 1999. Sacramento, Calif. 10 Mar.

Clingeleffer, P.R. 1989. Minimal pruning of cordon trained vines. Proc. 2nd Intl. Seminar on Mech. Pruning of Vineyards. Treviso, Italy. p. 112120.

Clingeleffer, P.R. 1992. Development of management systems for low cost, high quality wine production and vigour control in cool climate Australian vineyards. Proc. 3rd Intl. Cool Climate Viticult. Symp., Geisenheim, Germany. p. 130-134.

Clingeleffer, P.R. 1993. Vine response to modified pruning practices. Proc. 2nd N.J. Shaulis Grape Symp., Fredonia, N.Y. p. 20-30.

Clingeleffer, P.R. and J.V. Possingham. 1987. The role of minimal pruning of cordon-trained vines (MPCT) in canopy management and its adoption in Australian viticulture. Australian Grapegrower Winemaker 283:17-23.

Fendinger, A.G., R.M. Pool, R.M. Dunst, and R. Smith. 1996. Effect of mechanical thinning minimally-pruned 'Concord' grapevines on fruit composition. Proc. 4th Intl. Symp. on Cool Climate Viticult. and Enol. p. IV 13-17.

Fisher, K.H., B. Piott, and J. Barkovic. 1996. Adaptability of Labrusca and French hybrid grape varieties to mechanical pruning and mechanical thinning. Proc. 4th Intl. Symp. on Cool Climate 
Viticulture and Enology. p. IV 33-39.

Fitzpatrick, D.F., S.L. Hirschfield, and R.G. Coffey. 1993. Endothelium-dependent vasorelaxing activity of wine and other grape products. Amer. J. Physiol. 265:H774-H778.

Haight, K.G., B.H. Gump, and R.K. Striegler. 1995. Evaluation and characterization of Concord-type grape juice concentrates from the San Joaquin Valley. Calif. Agr. Tech. Inst. Publication \#951002.

Iland, P., A. Ewart, and J. Sitters. 1993. Techniques for chemical analysis and stability tests of grape juice and wine. Patrick Iland Wine Promotions, South Australia.

Jang, M., L. Cai, G.O. Udeani, K.V. Slowing, C.F. Thomas, C.W.W. Beecher, H.S.S. Fong, N.R. Farnsworth, A.D. Kinghorn, R.G. Mehta, R.C. Moon, and J.M Pezzuto. 1997. Cancer chemopreventive activity of resveratrol, a natural product derived from grapes. Science 275:218-220.

Lake, C.B., R.K. Striegler, P.S. Verdegaal, G.T. Berg, and J.A. Wolpert. 1996. Influence of training system on growth, yield, fruit composition and Eutypa incidence of Cabernet Sauvignon grapevines. Proc. 4th Intl. Symp. on Cool Climate Viticult. and Enol. p. III 19-26. Larsen, D. 2000. Getting the real juice-trade imbal- ance may offset juice growth. American Vineyard. 9:28.

Moore, J.N., J.R. Morris, and J.R. Clark. 1993. 'Sunbelt', A new juice grape for the southcentral United States. HortScience 28:859-860.

Morris, J.R. 1998. Factors influencing grape juice quality. HortTechnology. 8:471-478.

Morris, J.R. 2000. Past, present, and future of vineyard mechanization. Amer. J. Enol. and Viticult. Proc. of the Amer. Soc. Enol. Viticult. 50th Anniversary Annu. Mtg. Seattle, Wash. 19-23 June. 155-164.

Morris, J.R. and D.L. Cawthon. 1980a. Yield and quality response of 'Concord' grapes to training systems and pruning severity in Arkansas. J. Amer. Soc. Hort. Sci. 105:307-310.

Morris, J.R. and D.L. Cawthon. 1980b. Mechanical trimming and node adjustment of cordontrained 'Concord' grapevines. J. Amer. Soc. Hort. Sci. 105:310-313.

Morris, J.R. and D.L. Cawthon. 1980c. Mechanical pruning of cordon-trained 'Concord' grapevines. Ark. Farm Res. 29:12.

Morris, J.R. and D.L. Cawthon. 1981. Yield and quality response of 'Concord' grapes (Vitis labrusca L.) to mechanized vine pruning. Amer. J. Enol. Viticult. 32:280-282.

Morris, J.R. and R.K. Striegler. 1996. Grape Juice.
In: L. Somogyi (ed.) Processing Fruits: Science and Technology. Vol 2. Technomic Pub. Co. Lancaster, $\mathrm{Pa}$.

Morris, J.R., D.L. Cawthon, and C.A. Sims. 1984 Long-term effects of pruning severity, nodes per bearing unit, training system and shoot positioning on yield and quality of 'Concord' grapes. J. Amer. Soc. Hort. Sci. 109:676-683.

Olmo, H.P. and A. Koyama. 1962. 'Niabell' and 'Early Niabell.' Calif.. Agr. Expt. Sta. Bul. \#790.

Poste, L.M., D.A. Mackie, G. Butler, and E. Larmond. 1991. Laboratory methods for sensory analysis of food. Res. Branch Agr. Canada Publication 1864/E.

Pool, R.M., R.E. Dunst, D.C. Crowe, H. Hubbard, G.E. Howard, and G. DeGolier. 1993. Predicting and controlling crop on machine or minimal pruned grapevines. Proc. 2nd N.J. Shaulis Grape Symp. Fredonia, N.Y. p. 31-45.

SAS Institute. 1985. SAS user's guide statistics, 5th ed., SAS Inst., Cary, N.C.

Smith, R.L., R.M. Pool, A.D. Fendinger, J. Barnard, and T.E. Acree. 1996. Effects of crop load on the flavor character of Concord grape juice determined by descriptive sensory analysis. Proc. 4th Intl. Symp. on Cool Climate Viticult. and Enol. p. IV 24-27. 